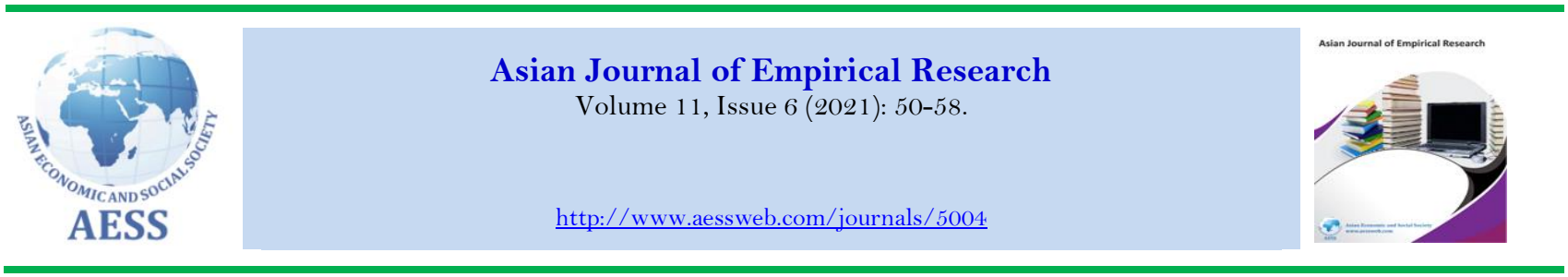

\title{
LINKING WATER ACCESS AND EDUCATION IN THE SUSTAINABLE DEVELOPMENT GOALS IN SUB-SAHARAN AFRICA
}

\section{Le Roi Nso Fils}

\section{Article History}

Received: 27 August 2021

Revised: 13 September 2021

Accepted: 18 October 2021

Published: 15 November 2021

\section{Keywords \\ Water access \\ Education \\ Parliament women \\ Government effectiveness.}

\section{JEL Classification}

H54; I2 1; O55.
University of OMAR BONGO, Centre International de Recherche en Economie et Gestion pour le Développement (CIREGED), Gabon.

$\triangle$ nsofils2002@yahoo.fr

Contribution/Originality: Despite the important literature on the relationship between access to drinking water and education, no macroeconomic study has yet highlighted the relationship between the two variables. This limitation of the literature constitutes the main contribution of this article. Subsidiarily, this article analyzes the contribution of parliament women in the transmission of the effects of access to water on education.

DOI: $10.18488 /$ journal.1007.2021.116.50.58

$\operatorname{ISSN}(\mathrm{P}):$ 2306-983X/ ISSN(E): 2224-4425

How to cite: Le Roi Nso Fils (2021) Linking Water Access And Education in the Sustainable Development Goals in Sub-Saharan Africa. Asian Journal of Empirical Research, 1 1(6), 50-58. 10.18488/journal.1007.2021.116.50.58

(C) 2021 Asian Economic and Social Society. All rights reserved.

\section{INTRODUCTION}

Education is an economic good because it is not easy to obtain and therefore must be distributed. It is seen as both a consumer and a capital good, as it provides utility (satisfaction) to the consumer and also serves as an input to develop the human resources necessary for economic and social transformation. The human capital theory is based on the assumption that formal education is necessary to improve the productive capacity of a population.

Despite the progress made by the Millennium Development Goals (MDGs) in 2015, the number of out-of-school children of primary school age worldwide is 57 million (United Nations, 2015). It is for this reason that ensuring quality education for all and at all ages is one of the overarching objectives, set at the heart of the 2030 Agenda of Sustainable Development Goals (SDGs). Education is one of the basic needs for human development and a contribution to poverty reduction (Sivakumar \& Sarvalingam, 2010). It is necessary for national development and a prosperous society.

Human capital theorists (Becker, 1962; Lucas, 1990; Mincer, 1958) argued that an educated population is a productive population. Improving the level of education of the population is an important condition for fostering the development of a country. It is therefore imperative to understand the factors that affect the level of education. The particular choice of the countries of sub-Saharan Africa is justified by the fact that, among the regions of the world, sub-Saharan Africa has the highest rates of exclusion in education. In fact, more than a fifth of children aged around 6 to 11 are out of school, followed by a third of children aged around 12 to 14 and almost $60 \%$ of young people aged 
around 15 to 17 are out of school (Institute of Statistics for UNESCO, 2019). In general, the African continent remains a first student when it comes to school exclusion. With a $21 \%$ exclusion rate, sub-Saharan Africa has a higher rate than North Africa (11\%) (Institute of Statistics for UNESCO, 2019).

Like education, the right of access to clean, fresh water is a fundamental human right (Samra \& Fawzi, 2011).

Water quality is a fundamental nutrient for life (Bonfante et al., 1999). And since there is no provision for water storage in the body, all water loss over a period in an individual must be replaced. The thirst signal is not triggered until the body mass loss of $1-2 \%$ has been achieved and the kidneys have already started to concentrate urine. While a decrease of less than $10-20 \%$ in body weight is unlikely to be fatal, dehydration does have short- and long-term consequences.

In addition to its nutritional role, it plays an essential role in supporting economic development. However, its quality and quantity are determining factors that influence its function for the environment, economy and social needs (Garcia, 1998; Young, Dooge, \& Rodda, 1994). According to Biswas (2004), water problems affect several development sectors such as agriculture, industry, environment, health and education.

When the MDGs expired in 2015, only a few countries in Africa had succeeded in halving the proportion of people without access to safe drinking water, and none had been able to meet the goal of sanitation (UNICEF and WHO, 2015). The WHO / UNICEF Joint Monitoring Program for Water Supply and Sanitation estimates that $32 \%$ of the population of sub-Saharan Africa, or about 319 million people, do not have access to an improved drinking water source, while $70 \%$ or about 695 million people did not have access to sanitation. With the adoption of the Sustainable Development Goals (SDGs) in 2015, the African continent places great hope in the achievement of Goal 6 - ensure access to water and sanitation for all by 2030.

Despite this progress, in $2017,29 \%$ of the world's population still did not have access to safe drinking water and about $55 \%$ did not have access to sanitation (UNICEF \& WHO, 2019). In sub-Saharan Africa, where the situation remains the most worrying, $39 \%$ of the population does not have access to a source of drinking water, compared to $69 \%$ who do not have access to improved sanitation (UNICEF \& WHO, 2019). In this part of the world, significant disparities between rural and urban areas persist, with only $45 \%$ of the rural population having access to safe drinking water, compared to $84 \%$ of the urban population. Likewise, only $22 \%$ of the rural population has access to improved sanitation, compared to $44 \%$ of the urban population (UNICEF \& WHO, 2019).

Unequal access to water and sanitation can translate into inequalities in health and education. When not connected to the water and sewer system, household members, especially children, may be at greater risk of contagion from water-related and water-borne diseases that prevent them go to school and be successful in their studies. Children may end up spending more time collecting, transporting and storing water and sewage than going to school or preparing homework. Water shortages and poor functioning water and sewerage systems can reduce the efficiency of education and health spending by all levels of government. However, most rural areas in developing countries do not have an improved water supply and the impact has worsened further due to high population growth (United Nations, 2010).

In rural areas of poor countries, water supply is more of a physical labor to obtain water or to draw water from a well and carry it a considerable distance from sources. In addition, it consumes a significant part of the time (Cherutich, Timothy, \& Quinter, 2015). When water is not available on household premises, distance to the water source becomes a critical variable for children's health and development. A shorter distance to the water source is associated with a lower incidence of diarrhea, fever and cough, lower infant mortality, and better height and weightfor-age scores (Pickering \& Davis, 2012; Rakodi, 1999).

In contrast, households may have more time available to engage in income-generating activities with better access to water and sanitation services (Range, Griesinger, Dachs, Bittner, \& Tavares, 2002). Better access to water not only increases household labor productivity through health gains, but it also leads to a reduction in communicable diseases within communities. In many societies, women and girls take care of household chores and water collection, transport, storage and handling. Breaking the cycle of poverty for women, through access to water, can translate into better outcomes for their children. Women's work increases their financial independence and bargaining power within the household, which improves the well-being of children (Van \& Gayatri, 2010).

The sexual division of labor influences access and control over water resources. Since women are responsible for household water collection in developing countries, some of them spend up to $25 \%$ of their productive time fetching water (Sullivan, 2001). In fact, a study by Nigam, McCallum, Thrun, and Mitchell (1998) on a watershed in South Asia showed that women and girls withdraw twice the amount of water per year than men and boys. Thus, the time women spend fetching water affects the time available to them for paid work and education.

These differences in water use and access are explained by divergent social positions between men and women in developing countries (Crow \& Farhana, 2002). In these countries, women have the primary responsibility for performing household chores, including collecting water (Elson, 1995). Indeed, in non-industrialized countries, men control land, finances, industry and government, and therefore, they tend to control access to water.

In water management practice, water-using communities tend to be predominantly female, while decisionmaking communities tend to be predominantly male (Cleaver \& Elson, 1995; Zwarteveen \& Meinzen-Dick, 2001). Even when water user associations are established to give all users a role in governance, other more powerful governance institutions may continue to dictate water use and control water supply (Cleaver \& Elson, 1995).

Access to water and sanitation services impacts academic performance at school in two different ways. First, water-related diseases are transmitted through the following routes: water-borne diseases (such as cholera and typhoid), water-related diseases (eg trachoma), water-borne diseases water and vector-borne infections (such as malaria, filariasis and dengue) and water-borne infections (such as legionellosis) (Hutton, 2012). Thus, better water 
and sanitation services help households save on health care and improve productivity. Second, studies have shown that dehydration can impair cognitive discrimination and short run memory (Khanna, 2008). As a result, lack of water adversely affects academic performance by reducing their cognitive abilities.

Empirically, work on the relationship between access to water and education is almost non-existent. Based on a case study in a poor rural district in India, James et al. (2002) found that when improvements in water access are linked to opportunities for microenterprises, time spent collecting water is converted into earned income. In areas where women and girls are responsible for collecting water, these results suggest that, i) "better access to water" would influence the participation of women and girls in daily activities, ii) time spent collecting water would increase women's wages through increased non-market production and, iii) time spent collecting water for girls would result in higher levels of education. Santiago Ortiz-Correa, Resende Filho, and Dinar (2016) analyzed the effect of access to water and sanitation on education in some municipalities in Brazil. Using an instrumental approach, the authors found that access to water and sanitation services has a positive and significant effect on schooling, when measured by the number of school years completed. These positive effects call for the expansion of lagging sewage systems across the country, both at home and at school. Demie, Bekele, and Seyoum (2016) follows suit and analyzes the impact of accessibility to water on girls' and women's participation in education and other activities in Wuchale and Jidda Woreda (Ethiopia). The study is carried out on a sample of 197 households. The following results emerge from this study: i) An individual obtains water by walking an average distance of $2.78 \pm 0.81 \mathrm{~km}$ from their residential area, which is above the maximum distance standard $(1 \mathrm{~km})$ set by the WHO and the UNICEF; ii) the study also showed that about $5.23 \pm 2.82$ hours per day were spent by girls and women fetching water. Even after traveling long distances and spending many hours a day, the water they get lacks sanitation and hygiene as they use it together with livestock and other living things; iii) Poor access to drinking water coupled with illiteracy (73.1\%) and the prevalence of water-borne diseases strongly influenced the participation of girls and women in education, agricultural production and other development activities in the study area. This was in line with the conclusions of Cherutich et al. (2015) who asserts that the opportunity cost of collecting water has social and economic dimensions. They further emphasized this point because, when the burden of water collection falls disproportionately on women and children, it has a cumulative effect on children's education, health and safety, including the erosion of their emotional well-being.

Although scarce, work on the relationship between access to drinking water and education is reduced to microeconomic analyzes. No macroeconomic study has yet been conducted on the relationship between the two variables. This study aims to fill this gap in the literature by analyzing the effect of access to water on education in sub-Saharan Africa where the exclusion rate in education is the highest among all regions of the world. Indeed, easy access to drinking water should not only reduce the time spent by children per day to fetch drinking water but improve their school performance through more time devoted to studies.

But in view of the high school exclusion rate in SSA, this calls on us to take a look at the relationship between access to water and education in this region. In addition, given the fact that water collection is mainly the responsibility of girls and women, they would be in a better position to master the various constraints related to access to water. To this end, can a significant increase in women's access to power bodies (in parliament, for example) play a role in the transmission of the effects of access to water on education?

The rest of the paper is organized as follows. Section 2 describes the data and methodology used to capture the link between water access and education. Section 3 discusses our empirical results, while section 4 concludes.

\section{DATA AND METHODOLOGY}

\subsection{Data}

We study a panel of 23 countries in sub-Saharan Africa with data for the period 2000-2018 from the World Development Indicators (WDI). The periodicity and the countries studied are chosen according to the constraints of data availability.

The dependent variable in this study is education. This variable is measured in this work through three indicators: the primary enrollment rate, the secondary enrollment rate and the tertiary level enrollment rate. These variables have already been used in the literature by authors such as Goldin and Katz (1997); Federman and Levine (2005) and Le Brun, Helper, and Levine (2011). The main independent variable in this study is access to drinking water. This variable is measured as the percentage of the population with access to safe drinking water in a given country.

A set of macroeconomic variables considered as determinants of education are used as control variables. These variables are largely based on the related education literature. These are access to sanitation, agriculture, population growth, manufacturing. The sources, the definitions of the variables and the list of countries in our panel are summarized in the appendix (cf. Table A1 and Table A2).

Table 1 gives the summary statistics of the variables and Table 2 provides the results of the cross-dependency test of Pesaran (2004). Table 2 shows that all the variables admit a transverse dependence with regard to their probability which is zero. Finally, Table 3 shows the results of the stationarity test of Pesaran (2007). It emerges from this table that all the variables are stationary at level. A brief description of the expected signs is given below.

According to Santiago Ortiz-Correa et al. (2016), access to safe drinking water has a positive effect on education. Like access to water, access to sanitation also positively impacts education Santiago Ortiz-Correa et al. (2016). As for the relationship between agriculture and education, Engler and Kretzer (2014) found that there is a positive relationship between the two variables. Likewise, Bilsborrow (1978) argue that there is no relationship between population growth and education. According to Le Brun et al. (2011), manufacturing work has a negative effect on education. 
Table-1. Descriptive statistic

\begin{tabular}{c|c|c|c|c|c|c}
\hline Variables & Obs & Mean & Median & Std Dev & Min & Max \\
\hline Manuf & 437 & 9.51 & 9.20 & 4.42 & 0.23 & 21.21 \\
\hline Agriculture & 437 & 23.79 & 23.98 & 12.67 & 2.08 & 58.65 \\
\hline Popgr & 437 & 2.74 & 2.76 & 0.64 & 0.23 & 4.62 \\
\hline Water & 437 & 55.01 & 54.31 & 13.84 & 19.89 & 92.27 \\
\hline Sanitation & 437 & 25.71 & 22.69 & 14.26 & 4.32 & 74.82 \\
\hline Goveff & 437 & -0.84 & -0.83 & 0.45 & -1.74 & 0.69 \\
\hline Polist & 437 & -0.79 & -0.66 & 0.78 & -2.66 & 0.66 \\
\hline Woparl & 437 & 17.62 & 13.88 & 10.91 & 1.2 & 44.5 \\
\hline Peducation & 437 & 96.14 & 99.34 & 22.82 & 32.35 & 149.30 \\
\hline Seducation & 437 & 36.05 & 33.84 & 18.28 & 6.19 & 109.44 \\
\hline Teducation & 437 & 5.93 & 4.64 & 4.52 & 0.34 & 20.48 \\
\hline
\end{tabular}

Table-2. Pesaran (2004).

\begin{tabular}{c|c|c|c|c}
\hline Variables & CD-Test & P-Value & Corr & Abs (corr) \\
\hline Peducation & 22.14 & 0.000 & 0.319 & 0.609 \\
\hline Seducation & 52.32 & 0.000 & 0.755 & 0.909 \\
\hline Teducation & 51.08 & 0.000 & 0.737 & 0.797 \\
\hline Woparl & 22.80 & 0.000 & 0.32 & 0.619 \\
\hline Manufact & 8.49 & 0.000 & 0.122 & 0.423 \\
\hline Agriculture & 5.08 & 0.000 & 0.073 & 0.381 \\
\hline Popgr & 4.15 & 0.000 & 0.060 & 0.532 \\
\hline Water & 28.49 & 0.000 & 0.411 & 0.959 \\
\hline Sanitation & 20.73 & 0.000 & 0.299 & 0.971 \\
Goveff & 5.04 & 0.000 & 0.073 & 0.414 \\
\hline
\end{tabular}

Table-3. Pesaran stationarity test.

\begin{tabular}{|c|c|c|c|c|c|}
\hline Variables & CIPS* & $\mathrm{CV}(10 \%)$ & $\mathrm{CV}(5 \%)$ & CV (1\%) & Decision \\
\hline Peducation & $-2.18 * *$ & -2.07 & -2.15 & -2.32 & $\mathrm{I}(\mathrm{O})$ \\
\hline Seducation & $-2.22^{* *}$ & -2.07 & -2.15 & -2.32 & $\mathrm{I}(\mathrm{O})$ \\
\hline Teducation & $-2.43 * * *$ & -2.07 & -2.15 & -2.32 & $\mathrm{I}(\mathrm{O})$ \\
\hline Water & -2.56 *** & -2.07 & -2.15 & -2.32 & $\mathrm{I}(\mathrm{O})$ \\
\hline Sanitation & $-2.89 * * *$ & -2.07 & -2.15 & -2.32 & $\mathrm{I}(\mathrm{O})$ \\
\hline Manuf & $-2.387^{* * * *}$ & -2.07 & -2.15 & -2.32 & $\mathrm{I}(\mathrm{O})$ \\
\hline Popgr & $-3.199^{* * *}$ & -2.07 & -2.15 & -2.32 & $\mathrm{I}(\mathrm{O})$ \\
\hline Goveff & $-2.12^{*}$ & -2.07 & -2.15 & -2.32 & $\mathrm{I}(\mathrm{O})$ \\
\hline Agriculture & $-2.367^{* * * *}$ & -2.07 & -2.15 & -2.32 & $\mathrm{I}(\mathrm{O})$ \\
\hline Woparl & $-2.138^{*}$ & -2.07 & -2.15 & -2.32 & $\mathrm{I}(\mathrm{O})$ \\
\hline
\end{tabular}

2.2. Methodology

The aim of this paper is to investigate the impact of water access on education in sub-Saharan African countries. According to the recent literature on education (Santiago Ortiz-Correa et al., 2016), we formulate the following model:

Education $_{i t}=\beta_{0}+\beta_{1}$ Educaction $_{i t-1}+\beta_{2}$ Water $_{i t}+\beta_{3} X_{i t}+\mu_{i}+v_{t}+\varepsilon_{i t}(1)$

Where Water $_{i t}$, represents people using at least basic drinking water services (\% of population) for country $i$ in the period $t, E_{\text {ducation }}$ it is the level of education for country $i$ in the period $t, X_{i t}$ is a vector which includes all control variables, $\mu_{i}$ is an unobserved country-specific effect, $v_{t}$ is time specific effect, and $\varepsilon_{i t}$ is the error term.

This study uses the estimation methodology of the GMM system. Several reasons justify the use of this method. According to Roodman (2009), the necessary condition for the application of the GMM methodology is that the number of cross sections is greater than the time dimension. This is exactly the nature of our data since we are arranged over 23 countries and over 19 years. Also, the inclusion of the lagged dependent variable in our model could lead to a correlation with the fixed effect in the error term (Nickell, 1981) raising the problem of endogeneity. The GMM estimator has been widely used to solve the endogeneity problem that appears in the estimation of panel data (Arellano \& Bond, 1991; Arellano \& Bover, 1995; Blundell \& Bond, 1998). In addition, this estimator also takes into account the biases that appear due to country-specific effects and it also avoids the problems of simultaneity or reverse causality. The consistency of the GMM estimator depends on two tests: the validity of the assumption that the error term has no serial correlation (AR (2)) and the validity of the instrument (Hansen test). Too many instruments can seriously weaken and bias Hansen's overidentification restriction test, and therefore the rule of thumb is that the number of instruments should be less than the number of countries (Roodman, 2009). 


\section{RESULTS}

The results are presented in the various tables below. Table 4 presents the results of the impact of access to water on education through the GMM method. Table 5 reproduces the model presented in Table IV by introducing the transmission channels. The estimation regressions mutually satisfy the Hansen instrument validity test and the AR (2) serial correlation test.

Analysis of Table 4 shows that water access has a negative and significant effect on education. Thus, an increase in access to drinking water for a unit leads to a reduction in the enrollment rate of $13.8 \% ; 2.9 \%$ and $0.7 \%$ respectively for primary, secondary and tertiary education (column 1-3). This result is contrary to the work of Santiago OrtizCorrea et al. (2016) who found that access to water has a positive impact on education in Brazil. According to statistics from the joint (UNICEF and WHO, 2015) monitoring program for water supply and sanitation, it is estimated that $32 \%$ of the population of sub-Saharan Africa, or about 319 million people, do not have access to an improved drinking water source (Ndikumana \& Pickbourn, 2017). And in this region, school children are responsible for fetching water. As a result, an insufficient supply of water increases the time it takes for learners to collect water. Thus, a limited supply of water increases the likelihood that learners will drop out of school in search of drinking water.

Agricultural value added has a negative and significant effect on education. Thus, an increase in this value by $1 \%$ leads to a reduction in the registration rate of $0.8 \% ; 2.4 \%$ and $0.7 \%$ respectively for primary, secondary and tertiary education (column 1-3). This result is contrary to the work of Engler and Kretzer (2014) who found a positive effect of agriculture on education. This result can be explained by the fact that for financial reasons, some young people were forced to drop out of school to concentrate on agricultural activities in order to support their families. This is generally the case in rural areas where agricultural activities are more prosperous compared to urban areas.

As for the population, it has a negative and significant effect on education. Thus, a population increase of $1 \%$ leads to a decrease in the enrollment rate of $1.8 \%$; $0.62 \%$ and $0.42 \%$ respectively for primary, secondary and tertiary education (column 1-3). This result is contrary to that of Bilsborrow (1978) who found no link between the two variables. This result can be explained by the fact that population growth is faster in Africa compared to other regions of the world and therefore exceeds the construction of educational infrastructure, thus leading to overcrowding of schools which constitutes an obstacle to the quality of teaching and sometimes in unsanitary conditions not conducive to learning.

Regarding manufacturing value added, it has a negative and significant effect on education. Thus, an increase in the manufacturing value added of one unit leads to a reduction in the registration rate of $11.10 \% ; 6.91 \%$ and $3.06 \%$ respectively for primary, secondary and tertiary education. The reduction in school enrollment due to industrialization is explained by the fact that industrialization attracts young people to work in factories and according to Le Brun et al. (2011), it is difficult to combine manufacturing work and schooling. In addition, this result can also be explained by the fact that industrialization increases the need of young people to provide help at home, especially since SSA is the region that concentrates the highest rate of monetary poverty (41\%) in the world (World Bank, 2016) and the least work opportunity is seized by young people in order to improve their financial situation (see that of their family) often to the detriment of their education. We retain from this analysis that in a context of ambient poverty, industrialization increases the opportunity cost of education. This result is consistent with the work of De Pleijt (2018) who showed that industrialization has led to declining demand for education and literacy in England. The same observation has been made about the level and growth of secondary education in the United States (Goldin \& Katz, 1997).This situation has been described by Sanderson (1972) and Nicholas and Nicholas (1992) as the "deskilling hypothesis".

Columns (4-6) repeat the estimates from columns (1-3) by adding other control variables (government effectiveness and political stability), the objective being to test the sensitivity of our results. The results obtained show that the coefficients of the variables in columns 1-3 retain not only their signs but also their significance.

Considering that women have the primary responsibility for performing household chores, including fetching water (Elson, 1995) and that in non-industrialized countries, men control land, finances, industry and government, and therefore access to water (Crow \& Farhana, 2002); women would be better placed to master the various constraints related to access to water. To this end, can a significant increase in women's access to power bodies (in parliament, for example) play an important role in the transmission of the effects of access to water on education?

Table $\mathrm{V}$ gives the results of the effect of access to water on education, highlighting the role of women parliamentarians. The results of this table show that access to water has a negative and significant effect on all three levels of education. In contrast, the interaction variable (water * woparl) has a positive and significant effect on the three levels of education (column 1-3). This result can be explained by the fact that a significant proportion of women parliamentarians can constitute a lobby able of bringing the suffering of populations who have difficulty accessing drinking water to political decision-makers so that the latter can provide solutions for the greatest happiness of the populations. This improved access to water will not only decrease the time that students spent per day collecting water and will consequently decrease the school exclusion rate and improve the school performance of students. Given the fact that the sign of the interaction variable is different from the sign of the direct effect (no synergy effect), net effects are therefore necessary according to the contemporary literature (Asongu \& Nwachukwu, 2017; Asongu. \& Nchofoung, 2021). In the calculation process, the net effect of the effect of the interaction between women parliamentarians and access to water is -0.1009 for primary education (column 1). This value is obtained as (-0.1344 $+(17.62 * 0.019))$. In this calculation, 0.0019 is the interactive effect coefficient, -0.1344 is the direct effect coefficient and 17.62 is the average of the proportions of women parliamentarians as shown in the descriptive statistics table. By applying the above calculation in all our transmission mechanisms, it appears that despite the positive interactive 
effect of the variable women parliamentarians in the transmission of the effect of access to water on education, the direct negative effect outweighs this positive interactive effect producing net negative effects of access to water on the three levels of education for our sample. This result reveals that there is a threshold of women parliamentarians from which access to water contributes positively to education in SSA.

Table-4. Effect of water access on education.

\begin{tabular}{|c|c|c|c|c|c|c|}
\hline \multirow[t]{2}{*}{ Variables } & 1 & 2 & 3 & 4 & 5 & 6 \\
\hline & Peducation & Seducation & Teducation & Peducation & Seducation & Teducation \\
\hline Water & $\begin{array}{c}-0.1386^{* * * *} \\
(0.00)\end{array}$ & $\begin{array}{c}-0.0293^{*} \\
(0.06)\end{array}$ & $\begin{array}{c}-0.0077^{*} * * \\
(0.00)\end{array}$ & $\begin{array}{c}-0.1094^{* * * *} \\
(0.00)\end{array}$ & $\begin{array}{c}-0.0292^{* *} \\
(0.02)\end{array}$ & $\begin{array}{c}-0.0143^{* * *} \\
(0.00)\end{array}$ \\
\hline Agriculture & $\begin{array}{c}-0.8026 * * * \\
(0.00)\end{array}$ & $\begin{array}{c}-0.0245^{* *} \\
(0.01)\end{array}$ & $\begin{array}{c}-0.0076^{* * * *} \\
(0.00)\end{array}$ & $\begin{array}{c}-0.0827^{* * * *} \\
(0.00)\end{array}$ & $\begin{array}{c}-0.0733 * * * \\
(0.00)\end{array}$ & $\begin{array}{c}-0.0079^{* *} \\
(0.01)\end{array}$ \\
\hline Popgr & $\begin{array}{c}-1.8209^{* * * *} \\
(0.00)\end{array}$ & $\begin{array}{c}-0.6290^{*} \\
(0.06)\end{array}$ & $\begin{array}{c}-0.4239^{*} * * \\
(0.00)\end{array}$ & $\begin{array}{c}-1.5649^{* * * *} \\
(\mathrm{O} .00)\end{array}$ & $\begin{array}{c}-0.7295^{* *} \\
(0.02)\end{array}$ & $\begin{array}{c}-0.3705^{* * *} \\
(0.00)\end{array}$ \\
\hline Manuf & $\begin{array}{c}-0.1110^{* *} \\
(0.03)\end{array}$ & $\begin{array}{c}-0.0681^{*} \\
(0.05)\end{array}$ & $\begin{array}{c}-0.0306^{* * * *} \\
(0.00)\end{array}$ & $\begin{array}{c}-0.1137^{* * * *} \\
(0.00)\end{array}$ & $\begin{array}{c}-0.1427 * * * \\
(0.00)\end{array}$ & $\begin{array}{c}-0.0649^{* *} \\
(0.01)\end{array}$ \\
\hline Sanitation & $\begin{array}{c}0.0143 \\
(0.7)\end{array}$ & $\begin{array}{c}-0.0026 \\
(0.8)\end{array}$ & $\begin{array}{c}0.0011 \\
(0.6)\end{array}$ & $\begin{array}{c}-0.0071 \\
(0.8)\end{array}$ & $\begin{array}{c}-0.0156 \\
(0.51)\end{array}$ & $\begin{array}{c}-0.0031 \\
(0.4)\end{array}$ \\
\hline Goveff & & & & $\begin{array}{c}-1.3145 \\
(0.2)\end{array}$ & $\begin{array}{c}1.1832^{*} \\
(0.08)\end{array}$ & $\begin{array}{c}0.8219^{* * * *} \\
(0.00)\end{array}$ \\
\hline Polist & & & & $\begin{array}{c}0.5806 \\
(0.3)\end{array}$ & $\begin{array}{c}-0.2322 \\
(0.6)\end{array}$ & $\begin{array}{c}-0.0995 \\
(0.18)\end{array}$ \\
\hline Lag dependant & $\begin{array}{c}0.9386^{* * * *} \\
(0.00)\end{array}$ & $\begin{array}{c}1.0216^{* * * *} \\
(0.00)\end{array}$ & $\begin{array}{c}0.9974 * * * \\
(0.00)\end{array}$ & $\begin{array}{c}0.9412^{* * * *} \\
(0.00)\end{array}$ & $\begin{array}{c}1.0123^{* * * *} \\
(0.00)\end{array}$ & $\begin{array}{c}1.0123^{* * *} * \\
(0.00)\end{array}$ \\
\hline Cons & $\begin{array}{c}22.5369^{* * * *} \\
(0.00)\end{array}$ & $\begin{array}{c}5.1348^{* * * *} \\
(0.00)\end{array}$ & $\begin{array}{c}2.3424 * * * \\
(0.00)\end{array}$ & $\begin{array}{c}19.9513^{* * *} \\
(0.00)\end{array}$ & $\begin{array}{c}8.8303^{* * * *} \\
(0.00)\end{array}$ & $\begin{array}{c}3.5026^{* * *} \\
(0.00)\end{array}$ \\
\hline $\operatorname{AR}(1)$ & 0.02 & 0.02 & 0.00 & 0.02 & 0.02 & 0.00 \\
\hline $\operatorname{AR}(2)$ & 0.92 & 0.13 & 0.45 & 0.88 & 0.13 & 0.40 \\
\hline Prob(Sargan) & 0.98 & 0.21 & 0.92 & 0.98 & 0.19 & 0.93 \\
\hline Prob(Hansen) & 0.99 & 0.75 & 0.34 & 0.727 & 0.67 & 0.36 \\
\hline Instruments & 17 & 22 & 20 & 23 & 22 & 23 \\
\hline N. Obs & 414 & 414 & 414 & 414 & 414 & 414 \\
\hline
\end{tabular}

Note: ***, *** *: represent the significance thresholds at $1 \%, 5 \%$ and $10 \%$ respectively. Values in parentheses represent probabilities

The political thresholds for the variable women parliamentarians that cancel out the negative effect of access to water on the three levels of education in our sample are $70.73 ; 22.47$ and 35.66 are respectively for primary, secondary and tertiary education. The threshold of a variable is obtained by setting the derivative of the education variable with respect to this variable (women parliamentarians) equal to zero. Simply put, the threshold is the ratio of the unconditional effect to that of the conditional effect. Apart from the threshold of women parliamentarians necessary for access to water to positively impact primary education, the other threshold values affect policies here, because they are within the range of values reported in descriptive statistics $(1.2<$ threshold of women parliamentarians <44.5).

Apart from the interaction variable (water * woparl), we have also introduced another interaction variable that links access to water and government efficiency (Water * Goveff). By deploying the same techniques as before (calculation of net effects and calculation of the threshold), we found that despite the positive interactive effect of the variable government efficiency in the transmission of the effect of access to water on education, the direct negative effect outweighs this positive interactive effect producing net negative effects of access to water on the three levels of education for our sample (column 4-6). Moreover, the policy thresholds for the government efficiency variable that cancel out the negative effect of access to water on the three levels of education in our sample are $1.3 ; 1.24$ and 0.73 are respectively for primary, secondary and tertiary education.

\section{CONCLUSION AND POLICY IMPLICATIONS}

Several studies have been carried out within the framework of water access. However, no macroeconomic study has focused on the link between water access and education specifically in sub-Saharan African countries. This article examines how water access influences education in sub-Saharan Africa. Thus, this is the analysis of 23 countries in sub-Saharan Africa during the period 2000-2018. To carry out our investigation, the Generalized Moments Methods were used. Three main results emerged from this study. First, there is a negative relationship between water access and education. Second, the introduction of Parliament Women and goverment effectiveness have allowed us to see that they are channels through which SSA can improve the effectiveness of the water access towards education. Finally, the positive association between water access and education in sub-Saharan Africa is conditioned by the achievement of a certain threshold of parliament women and goverment effectiveness. Thus, it is important for the various African governments to encourage more women to access positions of power. Because a significant representation of the latter in the bodies of power (such as parliament) will allow them to plead nearby political decision-makers for an improvement in access to drinking water, which improvement has a positive impact on 
education. In addition to this measure, African leaders must further integrate the problem of access to water in their priorities because its scarcity has negative repercussions on education, health and many other sectors of activities.

\begin{tabular}{|c|c|c|c|c|c|c|}
\hline & 1 & 2 & 3 & 4 & 5 & 6 \\
\hline Variables & Peducation & Seducation & Teducation & Peducation & Seducation & Teducation \\
\hline Water & $\begin{array}{c}-0.1344^{* * * *} \\
(0.00)\end{array}$ & $\begin{array}{c}-0.1461 * * * \\
(0.00)\end{array}$ & $\begin{array}{c}-0.0321^{* * * *} \\
(0.00)\end{array}$ & $\begin{array}{c}-0.0613^{*} \\
(0.05)\end{array}$ & $\begin{array}{c}-0.0608 * * * \\
(0.00)\end{array}$ & $\begin{array}{c}-0.0090^{* * *} \\
(0.04)\end{array}$ \\
\hline Agriculture & $\begin{array}{c}-0.0658^{* * * *} \\
(0.00)\end{array}$ & $\begin{array}{c}-0.0157 \\
(0.3)\end{array}$ & $\begin{array}{c}-0.0088^{* * * *} \\
(0.00)\end{array}$ & $\begin{array}{c}-0.1042^{* * * *} \\
(0.00)\end{array}$ & $\begin{array}{c}-0.0246 * * * \\
(0.00)\end{array}$ & $\begin{array}{c}-0.0036 \\
(0.1)\end{array}$ \\
\hline Popgr & $\begin{array}{c}0.4667 \\
(0.1)\end{array}$ & $\begin{array}{c}-1.7030^{* * *} \\
(0.01)\end{array}$ & $\begin{array}{c}-0.5023^{* * *} * \\
(0.00)\end{array}$ & $\begin{array}{c}-0.7061 * * \\
(0.04) \\
\end{array}$ & $\begin{array}{c}-0.9473^{* *} \\
(0.02) \\
\end{array}$ & $\begin{array}{c}-0.1661^{* * *} \\
(0.03)\end{array}$ \\
\hline Manuf & $\begin{array}{c}0.0130 \\
(0.8)\end{array}$ & $\begin{array}{c}-0.0997 * * \\
(0.03)\end{array}$ & $\begin{array}{c}-0.0254^{* *} \\
(0.01)\end{array}$ & $\begin{array}{c}-0.0474 \\
(0.14)\end{array}$ & $\begin{array}{c}-0.1487 * * * \\
(0.00)\end{array}$ & $\begin{array}{c}-0.0051 \\
(0.37)\end{array}$ \\
\hline Sanitation & $\begin{array}{c}0.0331 \\
(0.3) \\
\end{array}$ & $\begin{array}{c}-0.0486^{*} \\
(0.6)\end{array}$ & $\begin{array}{c}-0.0009 \\
(0.7)\end{array}$ & $\begin{array}{c}-0.0370^{*} \\
(0.09) \\
\end{array}$ & $\begin{array}{c}-0.0041 \\
(0.5)\end{array}$ & $\begin{array}{c}0.0129 * * \\
(0.02) \\
\end{array}$ \\
\hline Woparl & $\begin{array}{c}-0.1612^{*} * * \\
(0.00)\end{array}$ & $\begin{array}{c}-0.2905^{* * *} * \\
(0.00)\end{array}$ & $\begin{array}{c}-0.5538 * * * \\
(0.00)\end{array}$ & & & \\
\hline Goveff & & & & $\begin{array}{c}-2.3615 \\
(0.1) \\
\end{array}$ & $\begin{array}{c}-2.2322^{*} \\
(0.09)\end{array}$ & $\begin{array}{c}-0.9078 * * * \\
(0.00)\end{array}$ \\
\hline Water*Woparl & $\begin{array}{c}0.0019^{* *} \\
(0.04)\end{array}$ & $\begin{array}{c}0.0065^{* * * *} \\
(0.00)\end{array}$ & $\begin{array}{c}0.0009^{* * * *} \\
(0.00)\end{array}$ & & & \\
\hline Water*Goveff & & & & $\begin{array}{c}0.0468^{* *} \\
(0.03)\end{array}$ & $\begin{array}{c}0.0487^{* *} \\
(0.01)\end{array}$ & $\begin{array}{c}0.0123 * * * \\
(0.00)\end{array}$ \\
\hline Lag dependent & $\begin{array}{c}0.9551^{* * *} * \\
(0.00)\end{array}$ & $\begin{array}{c}0.9860^{*} * * \\
(0.00)\end{array}$ & $\begin{array}{c}0.9971^{* * * *} \\
(0.00)\end{array}$ & $\begin{array}{c}0.9447^{* * *} * \\
(0.00)\end{array}$ & $\begin{array}{c}1.0446^{* * * *} \\
(0.00)\end{array}$ & $\begin{array}{c}0.9857^{* * * *} \\
(0.00)\end{array}$ \\
\hline Cons & $\begin{array}{c}13.5035^{* * * *} \\
(0.00)\end{array}$ & $\begin{array}{c}15.8267^{* * * *} \\
(0.00)\end{array}$ & $\begin{array}{c}3.9291^{* * * *} \\
(0.00)\end{array}$ & $\begin{array}{c}15.7501^{* * * *} \\
(0.00)\end{array}$ & $\begin{array}{c}8.0945^{* * * *} \\
(0.00)\end{array}$ & $\begin{array}{c}0.9122^{* * * *} \\
(0.00)\end{array}$ \\
\hline Net effects & -0.1009 & -0.0315 & -0.0162 & -0.1006 & -0.1017 & -0.0193 \\
\hline Threshold effects & 70.73 & 22.47 & 35.66 & 1.30 & 1.24 & 0.73 \\
\hline $\operatorname{Prob}(\mathrm{CHI} 2)$ & 0.00 & 0.00 & 0.00 & 0.00 & 0.00 & 0.00 \\
\hline $\operatorname{AR}(1)$ & 0.02 & 0.02 & 0.00 & 0.02 & 0.03 & 0.00 \\
\hline $\operatorname{AR}(2)$ & 0.95 & 0.13 & 0.46 & 0.93 & 0.13 & 0.48 \\
\hline Prob(Sargan) & 0.79 & 0.22 & 0.92 & 0.63 & 0.86 & 0.32 \\
\hline Prob(Hansen) & 0.85 & 0.64 & 0.43 & 0.66 & 0.85 & 0.29 \\
\hline Instruments & 22 & 22 & 21 & 21 & 22 & 21 \\
\hline Nb. Observations & 414 & 414 & 414 & 414 & 414 & 414 \\
\hline Countries & 23 & 23 & 23 & 23 & 23 & 23 \\
\hline
\end{tabular}

Funding: This study received no specific financial support.

Competing Interests: The author declares that there are no conflicts of interests regarding the publication of this paper.

Views and opinions expressed in this study are the authors' views and opinions; the Asian Journal of Empirical Research shall not be responsible or answerable for any loss, damage, or liability, etc. caused in relation to/arising out of the use of the content.

\section{REFERENCES}

Arellano, M., \& Bond, S. (1991). Some tests of specification for panel data: Monte Carlo evidence and an application to employment equations. The Review of Economic Studies, 58(2), 277-297.

Arellano, M., \& Bover, O. (1995). Another look at the instrumental variable estimation of error-components models. Journal of Econometrics, 68(1), 29-51. Available at: https://doi.org/10.1016/0304-4076(94)01642-d.

Asongu, S. A., \& Nwachukwu, J. C. (2017). Foreign aid and inclusive development: Updated evidence from Africa, $2005-2012$. Social Science Quarterly, 98(1), 282-298.

Asongu., S., \& Nchofoung, T. (2021). The terrorism-finance nexus contingent on globalisation and governance dynamics in Africa European Xtramile Centre of African Studies WP/21/016.

Becker, G. S. (1962). Investment in human capital: A theoretical analysis. Journal of Political Economy, 70(5, Part 2), 9-49.

Bilsborrow, R. E. (1978). The relationship between population growth and expansion of education systems in developing countries 1950-1970. The Pakistan Development Review, 17(2), 212-232. Available at: https://doi.org/10.30541/v17i2pp.212-232.

Biswas, A. K. (2004). Integrated water resources management: A reassessment: A water forum contribution. Water International, 29(2), 248-256. Available at: https://doi.org/10.1080/02508060408691775.

Blundell, R., \& Bond, S. (1998). Initial conditions and moment restrictions in dynamic panel data models. Journal of Econometrics, 87(1), 115-143. Available at: https://doi.org/10.1016/s0304-4076(98)00009-8.

Bonfante, L., Calò, L., D’Angelo, A., Favaro, S., Abaterusso, C., Mennella, G., . . Antonello, A. (1999). Water and Its effects when drunk cold. American journal of nephrology, 19(2), 182-184. Available at: https://doi.org/10.1159/000013448. 
Cherutich, J., Timothy, M., \& Quinter, O. (2015). Water access and sustainable rural livelihoods: A case of elementaita Division in Nakuru County, Kenya. International Journal of Science, Technology and Society, 3(1), 9-23.

Cleaver, F., \& Elson, D. (1995). Women and water resources: continued marginalisation and new policies (pp. 1-10). London: International Institute for Environment and Development.

Crow, B., \& Farhana, S. (2002). 'Gender, class, and access to water: Three cases in a poor and crowded delta'. Society and Natural Resources, 15(8), 709-724. Available at: https://doi.org/10.1080/08941920290069308.

De Pleijt, A. M. (2018). Human capital formation in the long run: Evidence from average years of schooling in England, $1300-$ 1900. Cliometrica, 12(1), 99-126.

Demie, G., Bekele, M., \& Seyoum, B. (2016). Water accessibility impact on girl and women's participation in education and other development activities: The case of Wuchale and Jidda Woreda, Ethiopia. Environmental Systems Research, 5(1), 1-12. Available at: https://doi.org/10.1186/s40068-016-0061-6.

Elson, D. (1995). Male bias in the development process. Manchester: Manchester University Press.

Engler, S., \& Kretzer, M. M. (2014). Agriculture and education: Agricultural education as an adaptation to food insecurity in Malawi. Universal Journal of Agricultural Research, 2(6), 224-231.

Federman, M., \& Levine, D. (2005). The effects of industrialization on education and Youth Labor in Indonesia. The BE Journal of Macroeconomics, 5(1), 1-34. Available at: https://doi.org/10.2202/1534-6005.1243.

Garcia, L. (1998). Strategy for integrated water resources management.env-125 sustainable development department. Washington, DC: Interamerican Development Bank.

Goldin, C., \& Katz, L. (1997). Why United States led in education: Lessons from secondary school expansion, 1910 to 1940. NBER Working Paper No. (6144).

Hutton, G. (2012). Global costs and benefits of drinking-water supply andsanitation interventions to reach the MDG target and universal coverage (Vol. 67). Geneva, Switzerland: World Health Organization.

Institute of Statistics for UNESCO. (2019). SDG 4 Data Digest How to Produce and Use the Global and Thematic Education Indicators.

James, A. J., Joep, V., Christine, V. W., Reema, N., Mita, P., \& Mihir, B. (2002). Transforming time into money using water: A participatory study of economics and gender in rural India. Natural Resources Forum, 26(3), 205-217. Available at: https://doi.org/10.1111/0165-0203.00022.

Khanna, G. (2008). The impact on child health from access to water and sanitation and other socioeconomic factors. HEI Working Paper No. 66.

Le Brun, A., Helper, S., \& Levine, D. I. (2011). The effect of industrialization on children's education-The experience of Mexico. Review of Economics and Institutions, 2(2), 1-34. Available at: https://doi.org/10.5202/rei.v2i2.31.

Lucas, R. E. (1990). Why doesn't capital flow from rich to poor countries? The American Economic Review, 80(2), 92-96.

Mincer, J. (1958). Investment in human capital and personal income distribution. Journal of Political Economy, 66(4), $281-302$.

Ndikumana, L., \& Pickbourn, L. (2017). The impact of foreign aid allocation on access to social services in sub-Saharan Africa: The case of water and sanitation. World Development, 90, 104-114. Available at https://doi.org/10.1016/j.worlddev.2016.09.001.

Nicholas, S. J., \& Nicholas, J. M. (1992). Male literacy," deskilling," and the Industrial Revolution. The Journal of Interdisciplinary History, 23(1), 1-18. Available at: https://doi.org/10.2307/205479.

Nickell, S. (1981). Biases in dynamic models with fixed effects. Econometrica: Journal of the Econometric Society, 49(6), 1417-1426. Available at: https://doi.org/10.2307/1911408.

Nigam, K., McCallum, A., Thrun, S., \& Mitchell, T. (1998). Learning to classify text from labeled and unlabeled documents. Paper presented at the In AAAI-98.

Pesaran, M. H. (2004). General diagnostic tests for cross section dependence inpanels. Cambridge Working Papers in Economics No. 0435, Faculty of Economics, University of Cambridge.

Pesaran, M. H. (2007). A simple panel unit root test in the presence of cross-section dependence. Journal of Applied Econometrics, 22(2), 265-312. Available at: https://doi.org/10.1002/jae.951.

Pickering, A. J., \& Davis, J. (2012). Freshwater availability and water fetching distance affect child health in sub-Saharan Africa. Environmental Science \& Technology, 46(4), 2391-2397. Available at: https://doi.org/10.1021/es203177v.

Rakodi, C. (1999). A capital assets framework for analysing household livelihood strategies: Implications for policy. Development Policy Review, 17(3), 315-342. Available at: https://doi.org/10.1111/1467-7679.00090.

Range, S., Luiz Carlos, Griesinger, M. O., Dachs, J. N. W., Bittner, M. A., \& Tavares, S. (2002). Inequities in access to and use of drinking water services in Latin America and the Caribbean. Pan American Journal of Public Health, 11(5-6), 386-396. Available at: https://doi.org/10.1590/s1020-49892002000500013.

Roodman, J. (2009). How to do xtabond2: An introduction to difference and system GMM in Stata. STATA, 9(1), 86-136. Available at: https://doi.org/10.1177/1536867X0900900106.

Samra, S., \& Fawzi, S. (2011). The right to water in rural Punjab: Assessing equitable access to water through the Punjab rural water supply and sanitation project. Health Human Rights, 13(2), 36-49.

Sanderson, M. (1972). Literacy and social mobility in the industrial revolution in England. Past \& Present, 56(1), 75-104. Available at: https://doi.org/10.1093/past/56.1.75.

Santiago Ortiz-Correa, J., Resende Filho, M., \& Dinar, A. (2016). Impact of access to water and sanitation services on educational attainment. Water Resources and Economics, 14, 31-43. Available at: https://doi.org/10.1016/j.wre.2015.11.002.

Sivakumar, M., \& Sarvalingam, A. (2010). Human deprivation index : A measure of multidimensional poverty. Retrieved from: https://mpra.ub.uni-muenchen.de/22337/.

Sullivan, A. (2001). Cultural capital and educational attainment. Sociology, 35(4), 893-912. Available at: https://doi.org/10.1017/s0038038501008938.

UNICEF, \& WHO. (2019). Progress on household drinking water, sanitation and hygiene.

UNICEF and WHO. (2015). Progress on sanitation,and drinking water - 2015 update and MDG assessment.

United Nations. (2010). United nations sustainable management of water resources vital to achieving anti-poverty goals delegates told as general assembly high level dialogue marks world water day; General Assembly GA/10925. New York, NY, USA: United Nations.

United Nations. (2015). Millenium objectives for development 2015 report. Retrieved from: https://www.un.org/fr/millenniumgoals/reports/2015/pdf. 
Van, d. W. D., \& Gayatri, K. (2010). Access to water, womens's work and child outcomes. Policy Research Working Papers No. 5302.

World Bank. (2016). World development indicators. Washington D.C: World Bank.

Young, G., Dooge, J., \& Rodda, J. (1994). Global water resources issues. Cambridge: Cambridge University Press.

Zwarteveen, M., \& Meinzen-Dick, R. (2001). Gender and property rights in the commons: Examples of water rights in South Asia. Agriculture and Human Values, 18(1), 11-25.

\section{APPENDICES}

Table-A1. List of countries.

\begin{tabular}{c|c|c|c}
\hline Angola & Guinea & Nigeria & Zambia \\
\hline Burkina Faso & Kenya & Senegal & Zimbabwe \\
\hline Cameroon & Madagascar & Sierra Leone & \\
\hline Chad & Malawi & Soudan & \\
\hline Congo & Mali & South Africa & \\
\hline Congo, Dem. Rep & Mozambique & Tanzania & \\
\hline Cote d'Ivoire & Niger & Uganda & \\
\hline
\end{tabular}

Table-A2. Variable definitions.

\begin{tabular}{|c|c|c|c|}
\hline Variables & Signs & Variables definition (measurement) & Sources \\
\hline Manufacturing & Manuf & Manufacturing, value added (\% of GDP) & World Bank (WDI) \\
\hline Agriculture & Agriculture & Added value of agriculture ( $\%$ of GDP) & World Bank (WDI) \\
\hline Population & Popgr & Population growth (annual \%). & World Bank (WDI) \\
\hline Parliament women & Woparl & $\begin{array}{l}\text { Proportion of seats held by women in national } \\
\text { parliaments (\%) }\end{array}$ & World Bank (WDI) \\
\hline Primary education & Primary & School enrollment, primary (\% gross) & World Bank (WDI) \\
\hline Secondary education & Secondary & School enrollment, secondary (\% gross) & World Bank (WDI) \\
\hline Water & Water & $\begin{array}{l}\text { People using at least basic drinking water } \\
\text { services (\% of population) }\end{array}$ & \\
\hline Tertiary education & Tertiary & School enrollment, Tertiary (\% gross) & World Bank (WDI) \\
\hline Sanitation & Sanitation & $\begin{array}{l}\text { People using at least basic sanitation services } \\
\text { (\% of population) }\end{array}$ & World Bank (WDI) \\
\hline Governent Effectiveness & goveff & $\begin{array}{l}\text { Government effectiveness (measured by } \\
\text { perceptions of the quality of public services, } \\
\text { the quality of the public service and its degree } \\
\text { of independence from political pressures, the } \\
\text { quality of policy formulation and } \\
\text { implementation, and credibility of the } \\
\text { government's commitment to these policies. It } \\
\text { is between }-2,5 \text { and } 2.5 \text { ) }\end{array}$ & WGI, World Bank \\
\hline Political stability & Plista & $\begin{array}{l}\text { Political Stability and Absence of } \\
\text { Violence/Terrorism measures perceptions of } \\
\text { the likelihood of political instability and/or } \\
\text { politically-motivated violence, including } \\
\text { terrorism. Estimate gives the country's score } \\
\text { on the aggregate indicator, in units of a } \\
\text { standard normal distribution, i.e. ranging from } \\
\text { approximately -2.5 to } 2.5 \text {. }\end{array}$ & WGI, World Bank \\
\hline
\end{tabular}

